\title{
Planning the post-political city: exploring public participation in the contemporary Australian city
}

Crystal Legacy*, Faculty of Architecture, Building and Planning, The University of Melbourne, Melbourne, Vic, Australia

Nicole Cook, School of Geography and Sustainable Communities, The University of Wollongong, Wollongong, NSW, Australia

Dallas Rogers, School of Architecture, Design and Planning, The University of Sydney, Sydney, NSW, Australia

Kristian Ruming, Department of Geography and Planning, Macquarie University, Sydney, NSW, Australia

Corresponding author: Email: crystal.legacy@unimelb.edu.au

This is the author manuscript accepted for publication and has undergone full peer review but has not been through the copyediting, typesetting, pagination and proofreading process, which may lead to differences between this version and the Version of Record. Please cite this article as doi: $10.1111 / 1745-5871.12285$

This article is protected by copyright. All rights reserved. 


\section{Planning the post-political city: exploring public participation in the contemporary}

\section{Australian city}

Crystal Legacy*, Faculty of Architecture, Building and Planning, The University of Melbourne, Melbourne, Vic, Australia

Nicole Cook, School of Geography and Sustainable Communities, The University of Wollongong, Wollongong, NSW, Australia

Dallas Rogers, School of Architecture, Design and Planning, The University of Sydney, Sydney, NSW, Australia

Kristian Ruming, Department of Geography and Planning, Macquarie University, Sydney, NSW, Australia

Corresponding author: Email: crystal.legacy@unimelb.edu.au

\section{Cities and the public}

What scope is there for genuine debate over the future of Australian cities? A bourgeoning body of research gathered under the rubric of the "post-political city" is prompting the question of whether and how meaningful debate about the future of cities can occur in liberal democracies such as Australia. Situated within wider debates about the quality of politics in contemporary decision-making practices, post-political theorists caution that consensus-based planning in particular limits policy, action, and debate about the social and environmental injustices taking shape in cities. Works by Chantel Mouffe (2000, 2005), Jacques Rancière (1998), and Slavoj Žižek (1999) have set the tone for this late twentieth century postfoundationalist philosophy, highlighting the costs of consensus politics and suggesting that liberal democracies have entered a phase of post-democratization; the latter described by Swyngedouw (2011) as the disappearance of the political as a structuring agent in society. 
Some of the first urban scholars to engage with this post-foundationalist thinking align the post-political city with the influence of neoliberalism on public participation and urban governance, and thereby revealed the many ways in which public opinion was solicited and aggregated to the detriment of practices that would nurture political diversity and meaningful debate (Oosterlynck \& Swyngedouw, 2010; Swyngedouw, 2009, 2014).

In Australian cities, urban planning over the past thirty years has increasingly aligned with the principles of neoliberalism (see Gleeson \& Low, 2000). This alignment has occurred almost in parallel with movements away from expert-led planning towards consensual collaborative planning and decision-making, which were inspired by theories of communicative rationality (Innes, 1995). These shifts precipitated concerns that new practices in consensus-based planning could not fully accommodate diverse subjectivities, nor address the power-asymmetries that were reinforced through neoliberal planning (Purcell, 2009). Recognising these limits, Allmendinger and Haughton (2012) have argued that privileging consensus-building without critically reflecting on its relationship to public protest (when it occurs) may prevent us from seeing the different ways consensus-building seeks to continuously displace conflict in planning.

Post-political theorists claim that formal, state-created processes and spaces for participation increasingly offer no grounds for actual public debate, nor legitimate spaces for contestation (Metzger et al., 2015; Purcell, 2009; Rancière, 1998; Swyngedouw, 2009). As a result, debates about the future of the Australian city are not limited to official planning fora but instead extend beyond state-mandated participatory planning to include public-created spaces. We contend that in these spaces the negative impacts of planning are politicised. 


\section{The post-political Australian city}

In recent years, Australian cities have witnessed large-scale resident-led political campaigns targeting what those residents see as growing injustices in urban landscapes. Distorted by the pressure of neoliberalism, urban planning processes have decentred social equity and environmental sustainability by privileging economic rationality, competition, and privatisation. The construction of toll-roads in Brisbane and more recently in Sydney, Melbourne and Perth have exposed the impact of these decisions on the people of these cities. Like the resistance campaigns of the 1970s, including the now famous Green Bans resistance in Sydney (Burgmann and Burgmann, 1998) and the anti-freeway campaigns in Melbourne (Legacy, 2018, this issue), those being mounted now are also motivated by the mantra that cities are for people and not solely for producing profit. But, directly or subtly, the campaigns of today also galvanise against the impacts of unfettered neoliberalisation of cities and its governance, and the loss of public control of the city and its processes.

This observation is not intended to suggest that city planners have abandoned efforts to engage the public in planning their neighbourhoods, municipalities, and metropolitan regions. On the contrary, there have been many 'best practice' engagement techniques applied by all tiers of government to enable public participation over the past two decades: the Western Australian Government's attempts in the early 2000s to design large-town hall meetings based on the principles of deliberative democracy (Perth), or attempts to engage citizen jury processes in city budgeting exercises (Canada Bay; City of Melbourne) or to develop a longterm infrastructure strategy (Infrastructure Victoria). This is a considerable shift from the primacy of the expert-led, technocratic plans of the twentieth century to a comparatively 
more inclusive approach to planning now. Nevertheless, there is a perception that there are few opportunities to ask fundamental questions about the future of cities, or the allocation of resources, or the distribution of goods and services. It is such questions that attract opposition campaigns and movements, especially when they remain unanswered, or when prompted because negative externalities and lost opportunities costs reveal themselves over time.

It is notable that as these shifts occur towards intergenerational inequity, intense speculative development, and so-called "social cleansing" in diverse neighbourhoods, strategies of consultation have proliferated and failed (Darcy \& Rogers, 2014). For example, the compact city has remained a planning orthodoxy across a succession of metropolitan strategic planning documents in Australian capital cities, but with very little understanding of who benefits from this urban form, and who and what is lost. It is in this context that numerous scholars have declared a "crisis of participatory planning" in which this mode of engagement is rendered void of critical substance and influence (Darcy \& Rogers; 2014; Legacy, 2016: Legacy \& van den Nouwelant, 2015; Monno \& Khakee: 2012, Ruming, 2014a, 2014b). A 'consensus politics' generated in deliberative planning approaches and among the organisations and institutions of liberal democracies actually evades confrontational and challenging public discourses about how the city is constituted and re-created, for whom, and by whom. Instead, formal, state-led processes of city planning set out clearly defined sites for public engagement within which "participation" might occur, and these may limit broader expressions of engaged citizenship.

Despite limited conditions for formal public participation, agonistic traditions of democratic participation—including urban protest and activism—continue to punctuate planning 
decisions through informal, collective, grassroots action or through focused, sometimes sitespecific, oppositional campaigns (Iveson 2014). Outside formal decision-making arenas, urban residents are establishing new spaces to pursue their politics (McAuliffe \& Rogers, 2018). Beyond street protests, blockades, and social media campaigns conflict is expressed in the social patterns and population structures forming a central element of urban (political) change in Australia. This change can be observed by reference to the techniques and strategies by which residents, non-experts, and communities orient planning and political processes to locally desired outcomes (Cook at el., 2013; Ruming et al., 2012).

Recognising the resurgence of liberal and market values in Australian cities, this special section examines the possibility of meaningful debate and contestation over urban decisions and futures in politically constrained contexts. In doing so, it moves with the post-political times: critically examining the proliferation of deliberative mechanisms; identifying the informal assemblages of diverse actors that are taking on new roles in urban socio-spatial justice; and illuminating the spaces where informal and formal planning processes meet. These questions are particularly pertinent in understanding the processes shaping Australian cities and public participation today.

\section{Public participation in the post-political Australian city: A new research agenda}

Metzger et al. (2015) and Rancière (1998) ask in what ways is public participation in planning 'political' and how can resident action be used to counter these post-political tendencies? One of the challenges faced by all political and social movements is the question of their effectiveness over time: whether they "make a difference" and, if they do become 
popular, whether they become diluted and compromised? Rather than present informal action as an either/or proposition, the papers in this special section highlight the importance of asking how informal action reshapes and challenges the boundaries of what is possible in the post-political city. How does informal planning action render new trajectories and pathways of urban development both open and more visible? What organisations, practices, and resources exist in cities through which a new politics can be advanced? How representative are these groups of the city more broadly? Is it the case that the question is not 'how many people are represented here', but 'what is being said'? Perhaps, in the end, the most important feature of informal planning movements is not their size, but their unique capacity to articulate urban futures that embrace a philosophy of equity within uncertain social and environmental futures. To these ends, the question of what can be learnt from the experimental and visionary nature of urban planning movements and contemporary political movements is a scholarly question whose time has come.

The opening paper by Kristian Ruming examines the political struggle characterising a large urban regeneration project in Newcastle, New South Wales. Tracing efforts by state planning agencies to generate consensus about the need for inner city regeneration, Ruming examines how these efforts were destabilised by resident activists who mobilised an alternative urban vision; thereby revealing consensus around need for regeneration as opposed to consensus around the (material) form of regeneration. His paper illustrates how opponents' efforts to destabilise consensus claims made by the state can reconfigure the future city. Examples of urban residents stepping outside the formalised practices of public consultation to protest like 
in the case in Newcastle have become almost common practice in the area of transport infrastructure planning in Australian cities.

Crystal Legacy then analyses the establishment of Infrastructure Victoria to provide an empirical account of how infrastructure planning responds to public mobilisation in transport over time. Drawing together literature on transport politics and post-politics she examines the relationship between public protest and the formal practices of engagement, and concludes that, in sitting in relation to each other, they produce ever more savvy ways in which dissensus and consensus processes co-create each other.

Andrew Butt and Elizabeth Taylor show that public participation can also be interventionist. While exercised outside of the public submission, exhibition, and strategic plan-making processes, these resistance efforts are motivated by people seeking to change planning outcomes, if not urban practices more broadly. Focusing on the urban fringe they investigate conflict surrounding the establishment of intensive "broiler" poultry production in peri-urban Melbourne. Here Butt and Taylor mobilise Mouffe's problematisation of the negotiation of antagonism and Rancière's notion of the risk of a false consensus democracy to highlight critical issues of participatory planning. They argue that alternative politics emerge in response to changing understandings of place, the status of peri-urban regions and ethical issues associated with intensive farming, despite an apparent consensus around the agricultural identity of peri-urban regions and the presence of a code-based planning system. The papers assembled in this special section throw new light on the under-analysed elements of post-political theory-including the unchartered geographies of agonism and activism 
through which the alternative planning pathways discussed by Butt and Taylor emerge. To this end, Cameron McAuliffe and Dallas Rogers respond to Mouffe's call to move beyond a limited consensus politics, which serves to re-enforce post-political processes and perpetuate the urban agenda of an entrenched urban elite. They test Mouffe's theory empirically to see if the transition from antagonism to agonism is possible in Sydney. Mouffe contends that traditional antagonisms between "enemies" need to be moderated to a more mutual "adversarial" position, and McAuliffe and Rogers deploy these ideas to investigate how resident groups and urban alliances engage with the post-political city, in the face of reconfigured urban governance and regulatory frameworks.

The resident-led processes discussed by Ruming and Legacy show an appetite among people to ask questions that planning has foreclosed from public view, namely, what is the future of the city and what interventions and urban governance arrangements are necessary to ensure that this future remains in public ownership? This question forms the focus of Heather MacDonald's question “has planning been de-democratised in Sydney?" In her paper, MacDonald confronts the ongoing reconfiguration of urban governance and regulatory frameworks outlined in the paper by McAuliffe and Rogers. MacDonald argues that recent attempts by the New South Wales government at planning reform, council amalgamation, and the advent of a new metropolitan commission emerge as an (evolving) neoliberal effort to streamline development and de-democratise planning. Yet such efforts are contested by some urban residents and the impacts of these initiatives remain uncertain, at least in terms of development approval and economic performance. The capacity of state planning agencies to secure consensus using reformed planning frameworks emerges as inherently unstable. 
This collection of papers raises new questions for the study of politics and public participation in the Australian city. The papers extend post-political research by engaging with Australian urban contexts where planning authorities struggle against powerful national logics of property speculation and accumulation, yet find support from social and political movements for more democratic planning policies and practices.

\section{References}

Allmendinger, P. and Haughton, G., 2012. Post-political spatial planning in England: a crisis of consensus? Transactions of the Institute of British Geographers, 37(1), pp.89-103.

Burgmann, M., and Burgmann, V. (1998). Green bans, red union: environmental activism and the New South Wales Builders Labourers' Federation. Sydney, Australia: UNSW Press.

Cook, N., Taylor, E J., and Hurley, J., 2013. At home with strategic planning: reconciling residents' everyday territorialisation/s of home with policies and practices of residential densification. Australian Planner, 50(2), pp. 130-137.

Darcy, M. and Rogers, D., 2014. Inhabitance, place-making and the right to the city: public housing redevelopment in Sydney. International Journal of Housing Policy, 14(3), pp. 236-256.

Gleeson, B. and Low, N., 2000. Australian Urban Planning: New Challenges, New Agendas. Sydney, Australia: Allen \& Unwin.

This article is protected by copyright. All rights reserved. 
Innes, J.E., 1995. Planning theory's emerging paradigm: Communicative action and interactive practice. Journal of planning education and research, 14(3), pp.183-189.

Iveson, K., 2014. Building a city for 'The People': The politics of alliance-building in the Sydney Green Ban Movement. Antipode 46(4), pp. 992-1013.

Legacy, C., 2016. Transforming transport planning in the postpolitical era. Urban Studies, 53(14), pp. 3018-3124.

Legacy, C. and van den Nouwelant, R.,2015. Negotiating strategic planning's transitional spaces: the case of 'guerrilla governance' in infrastructure planning. Environment and Planning A, 47(1), pp. 209-226.

Metzger, J., Allmendinger, P. and Oosterlynck, S., eds, 2015. Planning against the political: Democratic deficits in European territorial governance. New York: Routledge.

Monno, V. and Khakee, A., 2012. Tokenism or political activism? Some reflections on participatory planning. International Planning Studies, $17(1)$, pp. 85-101.

Mouffe, C., 2000. The Democratic Paradox. London, U.K: Verso.

Mouffe, C., 2005. On the Political. London, U.K: Routledge.

Osterlynck, S. and Swyngedouw, E., 2010. Noise reduction: the postpolitical quandary of night flights at Brussels airport. Environment and Planning Ai 42(7), pp. 1577-1594.

Purcell, M., 2009. Resisting Neoliberalization: communicative planning or counterhegemonic movements? Planning Theory, 8(2), pp. 140-165.

Rancière, J., 1998. Disagreement. Minneapolis: University of Minnesota Press. 
Ruming, K., Houston, D. and Amati, M., 2012. Multiple Suburban Publics: Rethinking Community Opposition to Consolidation in Sydney. Geographical Research, 50(4), pp. 421-435.

Ruming, K., 2014a. Urban consolidation, strategic planning and community opposition in Sydney, Australia: unpacking policy knowledge and public perceptions. Land Use Policy, 39, pp. 254-265.

Ruming, K., 2014b. Social Mix Discourse and Local Resistance to Social Housing: The Case of the Nation Building Economic Stimulus Package, Australia. Urban Policy and Research, 32(2), pp. 163-183.

Swyngedouw, E., 2009. The Antinomies of the Post-political City: In Search of Democratic Politics of Environmental Production. International Journal of Urban and Regional Research, 33(3), pp. 601-620.

Swyngedouw, E., 2011. Interrogating post-democratization: Reclaiming egalitarian political spaces. Political Geography, 30(7), pp. 370-380.

Swyngedouw, E., 2014. Insurgent Architects, Radical Cities and the Promise of the Political. In: E. Swyngedouw, and W. Japhy, eds, The Post-Political and its Discontents: Space of Depoliticisation, Spectres Radical Politics. Edinburgh: Edinburgh University Press. pp. 169-188.

Žižek, S., 1999. The Ticklish Subject: The Absent Centre of Political Ontology. London: Verso.

This article is protected by copyright. All rights reserved. 


\section{University Library}

\section{- M M N E R VA A gateway to Melbourne's research publications}

Minerva Access is the Institutional Repository of The University of Melbourne

Author/s:

Legacy, C;Cook, N;Rogers, D;Ruming, K

Title:

Planning the post-political city: exploring public participation in the contemporary Australian city

Date:

2018-05-01

Citation:

Legacy, C., Cook, N., Rogers, D. \& Ruming, K. (2018). Planning the post-political city: exploring public participation in the contemporary Australian city. GEOGRAPHICAL RESEARCH, 56 (2), pp.176-180. https://doi.org/10.1111/1745-5871.12285.

Persistent Link:

http://hdl.handle.net/11343/284047 